\title{
RANDOMIZED EVALUATION ON THE CONSUMPTION OF ANTIBIOTICS IN COMMUNITY PHARMACIES
}

\author{
CORINA MOISA ${ }^{1 * *}$, ANDREEA MARGARETA VLAD ${ }^{1 *}$, ALIN TEUSDEA $^{2 *}$, OANA CADAR $^{3 *}$, \\ MARIA ALEXANDRA HOAGHIA ${ }^{3 \#}$, ROXANA LIANA STAN ${ }^{4 \#}$, ADRIANA TĂEREL $^{5 \#}$, \\ CLAUDIA JURCA ${ }^{1 \#}$, LAURA GRAȚIELA VICAS ${ }^{1 \#}$ \\ ${ }^{1}$ University of Oradea, Medicine and Pharmacy Faculty, Oradea, Romania \\ ${ }^{2}$ University of Oradea, Faculty of Environmental Protection, Oradea, Romania \\ ${ }^{3}$ INCDO-INOE 2000, Research Institute for Analytical Instrumentation, Cluj-Napoca, Romania \\ 4 "Iuliu Hațieganu” University of Medicine and Pharmacy, Faculty of Pharmacy, Cluj-Napoca, Romania \\ 5 "Carol Davila" University of Medicine and Pharmacy, Faculty of Pharmacy, Bucharest, Romania
}

*corresponding author: corinamoisa@hotmail.com

\#Authors with equal contribution

Manuscript received: January 2018

\begin{abstract}
According to the statistics, each year 400,000 Europeans develop infections with antibiotic-resistant bacterial strain, and 25,000 die due to the exhaustion of all therapeutic resources. These statistics are alarming, considering that medical services have become lately more and more accessible, but the "antibiotics era", namely the prescribing of these pharmacological agents on a large scale, generated the present situation. There is a category of patients who seek specialist medical services, yet many of them also make errors when it comes to the correct administration of the antibiotics prescribed. The emergence of antibiotic resistant strains occurred due to the of insufficient or excessive treatment schemes, insufficient doses or treatment duration. Physicians and pharmacists have an important role in limiting the occurrence and development of the antibiotics resistant strains. The objective of the present study was the comparative assessment of antibiotic's consumption in urban and rural areas, in a western region of Romania for both children and adults, the medicines being prescribed by physicians and monitored through community pharmacies. The study was conducted over 2 years and involved five types of active substances, namely amoxicillin, cefuroxime, clarithromycin, sulphametoxazole + trimethoprim and cefixime.
\end{abstract}

\section{Rezumat}

Conform unor statistici, 400.000 de europeni dezvoltă anual infecţii cu bacterii rezistente la antibiotice, iar 25.000 decedează în urma epuizării tuturor resurselor terapeutice. Aceste statistici sunt îngrijorătoare cu atât mai mult cu cât în ultima perioadă serviciile medicale au devenit mai accesibile, dar utilizarea pe scară largă a acestor agenți farmacologici în "epoca antibioticelor" a generat această situație. Există o categorie de pacienți care apelează la serviciile medicale de specialitate, dar cu toate acestea apar deficiențe în ceea ce privește administrarea corectă a antibioticelor prescrise de către medic. Dezvoltarea tulpinilor rezistente la antibiotice s-a datorat aplicării unor scheme de tratament insuficiente sau excesive, doze sau durate de tratament nerespectate. Un rol important în limitarea apariției şi dezvoltării acestor tulpini rezistente la antibiotice îl au medicii și farmaciștii, prin consiliere adecvată. Obiectivele prezentului studiu au fost compararea și evaluarea consumului de antibiotice în mediul rural și urban într-o regiune din vestul României, atât la copii cât și la populaţia adultă, antibioticele fiind prescrise de către medic și monitorizate prin farmacii comunitare. Studiul s-a desfăşurat pe o perioadă de doi ani și a cuprins cinci substanțe active diferite: amoxicilină, cefuroximă, claritromicină, sulfametoxazol + trimetoptim și cefiximă.

Keywords: antibiotics, community pharmacy, pharmaceutical care

\section{Introduction}

Since Flemming $\vec{s}$ huge discovery penicillin, antibiotics intake has gradually increased and the excessive consumption of antibiotics has led to an erosion in their efficiency and to the emergence of multi-drug resistant bacterial strains overlapping the development of new molecules able to treat the infectious diseases the population is more and more confronted with.

Another negative effect of the unjustified use of antibiotics is intestinal dismicrobism. In case of prolonged treatment with antibiotics, the intestinal flora is disbalanced and favours the development of pathogenic bacteria. Besides these negative effects, one must not forget the adverse effects of certain antibiotics on the liver, kidneys or ear [1, 2].

Antibiotics intake can be limited by a proper medical education of the population, through physicians' and pharmacists' active involvement. As for the prescription of antibiotics by the physicians, one cannot fail to notice an almost generalized situation referring to a difference in the choice of antibiotics prescribed to children 
compared to those for adults, often without prior antibiogram or radiography. Hospital specialists repeatedly draw attention to this aspect, citing situations in which, for example, the lack of radiography in the case of a patient with symptoms of bacterial infection may hide a superinfection of a lung tumour [3].

On a different note, family doctors confront the need to prescribe medication to patients who often see them when they are in a serious condition and in urgent need of therapy the waiting for the antibiogram $\vec{s}$ results triggering an acute evolution of the disease. Treatment of adult patients may often be tied to their financial situation, a high price leading to shorter the treatment scheme or to giving up drugs or replacing them to more affordable ones [10].

A common mistake with antibiotics intake by adults is that many of them discontinue treatment once the symptoms improve. The treatment period is shortened for different reasons, either financial ones, or, most of the times, out of convenience. Such errors occur mostly when the patients neglect the physicians and pharmacists advices $[5,6]$.

The literature data report population groups that are not aware that by administering the antibiotics the symptoms improve, but the bacterial infection persists even if their general state is better. Too early discontinuation of an antibiotic increases bacterial resistance and, after a while, the symptoms may return, worsened [11].

This is one of the causes leading to an increased antimicrobial resistance, cases in which current use antibiotics are no longer efficient. Currently available alternative treatments are more expensive, toxic and act much more slowly [8, 9]. Specialists have reached the conclusion that, if this excessive use of antibiotics continues, we will no longer have an effective treatment for diseases that are curable today.

An important aspect is that although there are people who don't need, nor take antibiotics, they are not protected from resistant bacterial strains, since they may develop anytime such an infection. Thus, some of our peers' excess affects the entire population [7].

There are increasing strategies adopted by the Romanian authorities to stop the excessive use of antibiotics, as a consequence of the high use of these medicines.

\section{Materials and Methods}

\section{Study design}

We have carried out a study over two years, between 01.01.2014 and 31.12.2015 regarding the use of antibiotics, both in adults and children, in a western region of Romania, in urban (UB) and rural $(\mathrm{RR})$ areas. The drugs ${ }^{-1}$ monitoring was performed through thirty community pharmacies in the urban area and thirty community pharmacies in the rural area whose antibiotics turnover was included in the study.

The pharmacies under study were chosen to represent both pharmacies in more remote areas of the cities, and pharmacies positioned in the central areas and in the close vicinity of hospitals and medical clinics.

We monitored the most usually substances prescribed in adults, namely amoxicillin (Amx), cefuroxime (Cfx), clarithromycin (Clari), sulphamethoxazole + trimethoprim $(\mathrm{S}+\mathrm{T})$ and cefixime. (Cefix). In children the active substances usually prescribed used were: amoxicillin (Amx), cefuroxime (Cfx), clarithromycin (Clari) and sulphametoxazole + trimethoprim $(\mathrm{S}+\mathrm{T})$. The subject study population was divided into four different groups, depending on the geographic area of origin.

The design of experiment included four geographical areas: urban areas (L1_UB, L2_UB, L3_UB and L4_UB), with their rural surroundings (L1_RR, L2_RR, L3_RR and L4_RR). The analysed factors were: location with 4 levels L1, L2, L3 and L4, that denotes the geographical areas of interest; LocType with 2 levels: UB for urban areas and RR for rural areas; the interaction factor Location*LocType with 8 levels: L1*RR, L2*RR, $\mathrm{L} 3 * \mathrm{RR}, \mathrm{L} 4 * \mathrm{RR}, \mathrm{L} 1 * \mathrm{UB}, \mathrm{L} 2 * \mathrm{UB}, \mathrm{L} 3 * \mathrm{UB}$ and L4*UB. All the data were expressed as means/thousand inhabitants of corresponding factor level.

\section{Statistical analysis}

All adults and children antibiotics consumptions were subjected to two-way analysis of variance (ANOVA), $\mathrm{p}<0.05$. The Tukey's pairwise multicomparison test $(\mathrm{p}<0.05)$ was done to compare the mean values between samples and location, location type and their interaction factors. The overall antibiotics consumption (i.e. antibiotics profile) comparisons between the studied locations, was investigated with a multivariate sequence: PCA (principal component analysis), ANOSIM (analysis of similitude, $\mathrm{p}<0.05$ ) and HCA (hierarchical cluster analysis). The univariate statistical analysis was done with GrapPad Prism 5.3 (GraphPad Software Inc., CA, USA). The multivariate statistical analysis was done with PAST version 3.12 (Paleontological Statistics software [4])

\section{Results and Discussion}

The number of prescriptions with various antibiotics was higher in the centrally located pharmacies compared to that of those in the more remote areas of the cities, even if often the patients' homes were not in the area they picked their medical prescription. 
FARMACIA, 2018, Vol. 66, 6

In view of these differences, we have chosen to use an average of the turnover of the pharmacies under study, for the certain antibiotics denoted. The frequency of antibiotic use as well as the type of antibiotics varied between the cities in urban areas and the ones in rural areas (Table I, Figure 1 and 2).

Table I

Factor Location: average values of antibiotics consumptions for adults

\begin{tabular}{cccccc}
\hline Location & $\mathbf{A m x}$ & $\mathbf{C f x}$ & Clari & S+T & Cefix \\
\hline RR & $71.29 \pm 44.07^{\mathrm{a}}$ & $3.54 \pm 2.76^{\mathrm{a}}$ & $3.65 \pm 1.58^{\mathrm{b}}$ & $1.91 \pm 0.99^{\mathrm{b}}$ & $1.56 \pm 0.89^{\mathrm{b}}$ \\
UB & $27.88 \pm 38.51^{\mathrm{b}}$ & $3.20 \pm 4.57^{\mathrm{a}}$ & $6.81 \pm 9.61^{\mathrm{a}}$ & $3.07 \pm 4.17^{\mathrm{a}}$ & $1.79 \pm 2.43^{\mathrm{a}}$ \\
\hline
\end{tabular}

Note: Different letters over each column denotes statistical significant mean differences from Tukey's post-hoc test $(\mathrm{p}<0.05)$. Amoxicillin (Amx), cefuroxime (Cfx), clarithromycin (Clari), sulphamethoxazole + trimethoprim (S+T), cefixime. (Cefix).

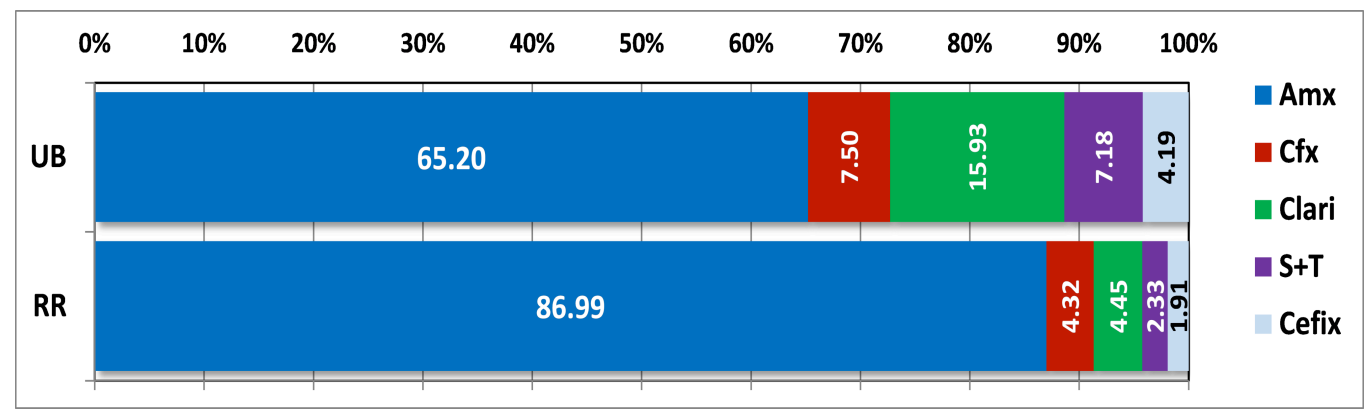

Figure 1.

Percentages of the adults' antibiotics average consumption

Table II

Factor Location*LocType: average values of antibiotics consumptions for adults

\begin{tabular}{|c|c|c|c|c|c|}
\hline $\begin{array}{c}\text { Location } \\
\text { *LocType }\end{array}$ & $\operatorname{Amx}$ & Cfx & Clari & $\mathbf{S}+\mathbf{T}$ & Cefix \\
\hline L1*RR & $58.93 \pm 26.46^{\mathrm{c}}$ & $2.89 \pm 2.36^{\mathrm{d}}$ & $3.08 \pm 0.91^{\mathrm{e}}$ & $1.53 \pm 0.47^{\mathrm{c}}$ & $1.32 \pm 0.31^{\mathrm{d}}$ \\
\hline $\mathbf{L} 2 * \mathbf{R R}$ & $74.48 \pm 9.35^{\mathrm{c}}$ & $2.93 \pm 0.84^{\mathrm{c}}$ & $5.52 \pm 1.07^{\mathrm{d}}$ & $2.73 \pm 0.23^{\mathrm{c}}$ & $1.73 \pm 0.79^{\mathrm{d}}$ \\
\hline $\mathbf{L} 3 * \mathbf{R R}$ & $46.78 \pm 7.31^{\mathrm{c}}$ & $3.74 \pm 0.89^{\mathrm{d}}$ & $3.03 \pm 1.10^{\mathrm{de}}$ & $1.55 \pm 0.19^{\mathrm{cd}}$ & $0.96 \pm 0.38^{\mathrm{cd}}$ \\
\hline $\mathbf{L} 4 * \mathbf{R R}$ & $182.17 \pm 6.28^{\mathrm{a}}$ & $8.48 \pm 2.99^{c}$ & $6.86 \pm 1.20^{\mathrm{c}}$ & $4.35 \pm 0.61^{b}$ & $3.75 \pm 1.11^{\mathrm{b}}$ \\
\hline $\mathbf{L} 1 * \mathrm{UB}$ & $6.33 \pm 1.54^{\mathrm{d}}$ & $0.65 \pm 0.13^{\mathrm{e}}$ & $1.50 \pm 0.28^{\mathrm{f}}$ & $0.69 \pm 0.06^{\mathrm{d}}$ & $0.42 \pm 0.05^{\mathrm{e}}$ \\
\hline $\mathbf{L} 2 * \mathbf{U B}$ & $119.61 \pm 27.48^{b}$ & $15.03 \pm 2.28^{\mathrm{a}}$ & $32.96 \pm 1.13^{\mathrm{a}}$ & $13.46 \pm 0.80^{\mathrm{a}}$ & $8.17 \pm 0.36^{\mathrm{a}}$ \\
\hline $\mathbf{L} 3 * \mathbf{U B}$ & $64.19 \pm 17.50^{c}$ & $6.93 \pm 1.02^{\mathrm{b}}$ & $15.90 \pm 0.55^{\mathrm{b}}$ & $7.01 \pm 0.45^{\mathrm{b}}$ & $3.91 \pm 0.53^{\mathrm{bc}}$ \\
\hline $\mathbf{L} 4 * \mathbf{U B}$ & $73.34 \pm 21.12^{\mathrm{c}}$ & $8.41 \pm 1.14^{\mathrm{b}}$ & $15.09 \pm 1.45^{\mathrm{b}}$ & $7.96 \pm 2.08^{b}$ & $4.41 \pm 0.41^{b}$ \\
\hline
\end{tabular}

Note: Different letters over each column denotes statistical significant mean differences from Tukey's post-hoc test $(\mathrm{p}<0.05)$.

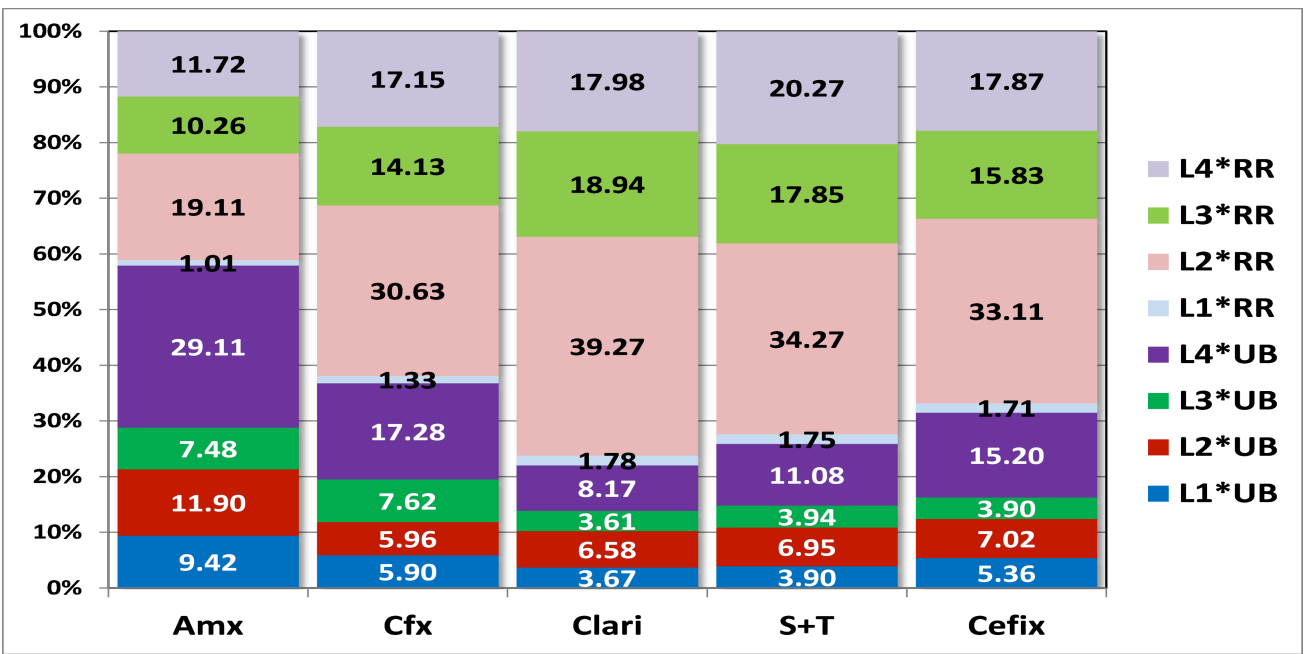

Figure 2.

Percentages of the adults ${ }^{-}$antibiotics use from different geographical areas

There was a higher frequency of antibiotics use, more affordable in terms of price, in the rural areas (amoxicillin) where the population has lower incomes, compared to the rural areas with higher incomes, 
FARMACIA, 2018, Vol. 66, 6

whether it comes to employees or retired people. In antibiotics containing (cefuroxime, clarithromycin) rural areas there was a higher consumption of (Figure 3).

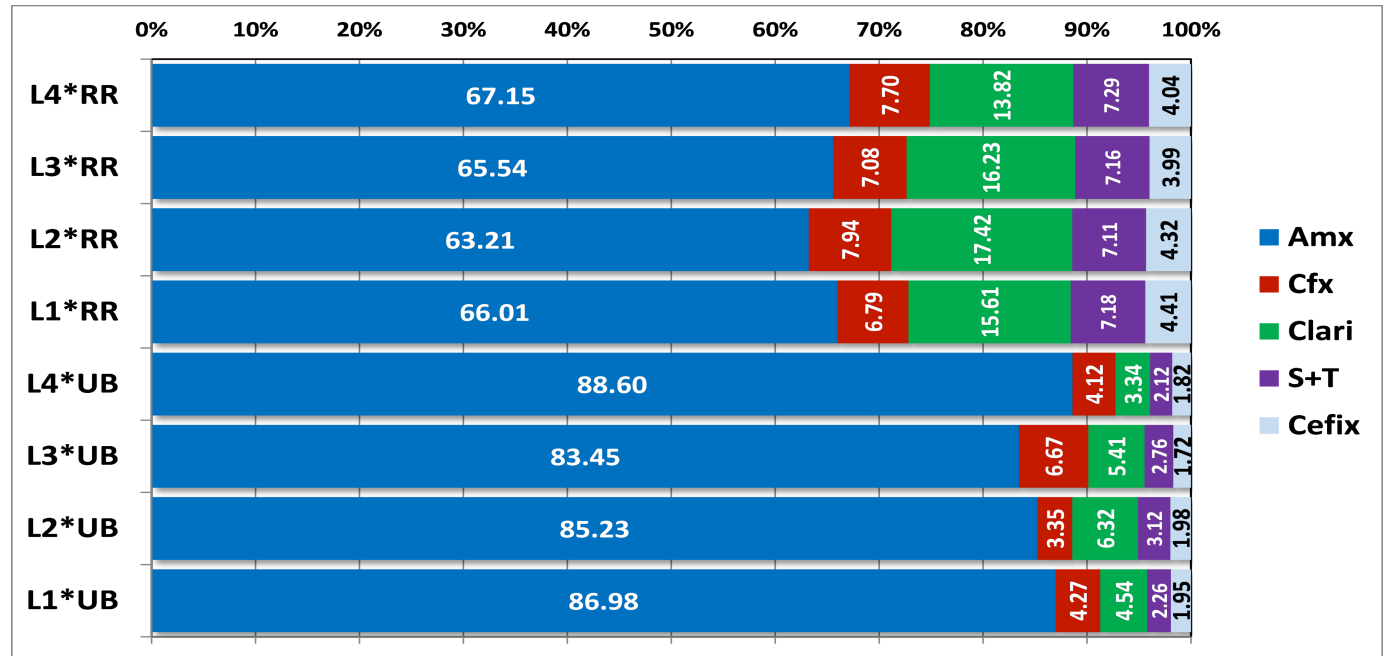

Figure 3.

Percentages of the adults' average consumption of antibiotics distributed on geographical areas

The situation was slightly different when to children, were involved as parents are more sensitive to their suffering and this makes them appreciate the physician prescribing antibiotics (see Table III and Table IV, Figures 4 - 6). The financial criterion no longer applied in this situation, as prescriptions for children are not payed by the tutors, but through the national insurance. Many parents were satisfied if the physician has prescribed a treatment containing expensive drugs, even if they are not payed, as in their opinion, the stranger the antibiotic is for them, the "stronger" it is, therefore its therapeutic effect is improved.

Table III

Factor Location: average values of the children antibiotics consumptions

\begin{tabular}{ccccc}
\hline Location & Amx & Cfx & Clari & S+T \\
\hline RR & $1.59 \pm 0.96^{\mathrm{b}}$ & $4.13 \pm 2.02^{\mathrm{a}}$ & $1.39 \pm 0.77^{\mathrm{a}}$ & $1.21 \pm 0.60^{\mathrm{b}}$ \\
$\mathbf{U B}$ & $4.74 \pm 7.18^{\mathrm{a}}$ & $3.43 \pm 4.64^{\mathrm{b}}$ & $1.36 \pm 1.97^{\mathrm{a}}$ & $2.13 \pm 3.26^{\mathrm{a}}$ \\
\hline
\end{tabular}

Note: Different letters over each column denotes statistical significant mean differences from Tukey's post-hoc test $(\mathrm{p}<0.05)$

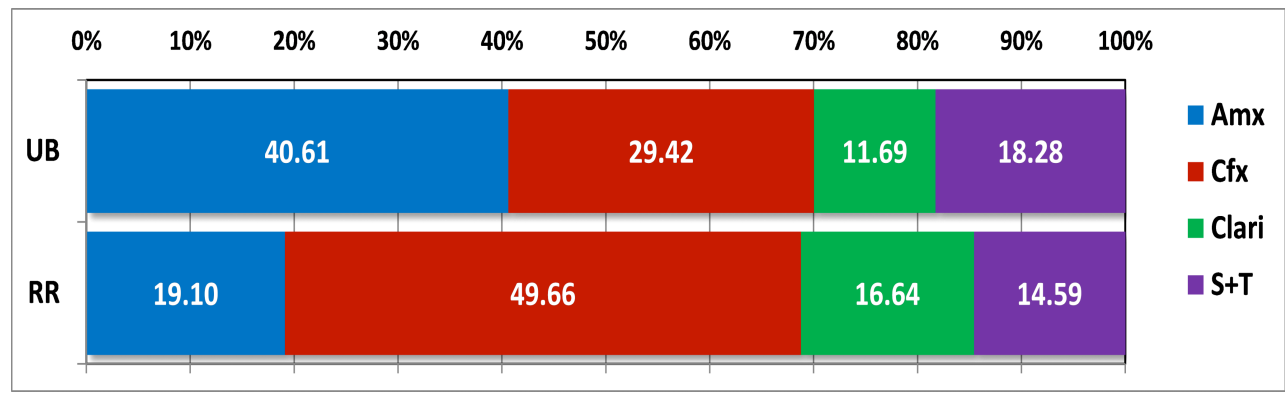

Figure 4.

Percentages of the children ${ }^{-1} \mathrm{~s}$ antibiotics average consumption

Many antibiotics prescribed to children also have an irritative effect on the gastric mucosa, which leads to an improper administration of antibiotics. In these situations, the parents resort to reducing the frequency of administration or the administration of a smaller antibiotic dose to prevent possible vomiting in children.

In some cases, the physicians report patients' pressure for having an antibiotic prescription. In these patient's opinion, a physician who does not prescribe antibiotics in case of fever, cough, sore throat or cold is not suitable. The dissatisfaction resulting from the lack of prescription a treatment to the patient considers as suitable for him/her often leads to changing the physician.

The results of the same study made in the same pharmacies, both in the urban area and the rural areas, for children, are presented in the Table IV, Figure 5 and 6. 
Factor Location*LocType: average values of antibiotics consumptions for children

\begin{tabular}{|c|c|c|c|c|}
\hline Location*LocType & Amx & $\mathbf{C f x}$ & Clari & $\mathbf{S}+\mathbf{T}$ \\
\hline $\mathbf{L} 1 * \mathbf{R R}$ & $1.21 \pm 0.52^{\mathrm{d}}$ & $3.31 \pm 0.34^{\mathrm{e}}$ & $1.12 \pm 0.25^{\mathrm{d}}$ & $1.05 \pm 0.36^{\mathrm{d}}$ \\
\hline $\mathbf{L} 2 * \mathbf{R R}$ & $2.33 \pm 0.37^{\mathrm{cd}}$ & $5.43 \pm 0.70^{\mathrm{d}}$ & $1.82 \pm 0.55^{\mathrm{c}}$ & $1.42 \pm 0.42^{\mathrm{d}}$ \\
\hline $\mathbf{L 3} * \mathbf{R R}$ & $1.38 \pm 0.12^{\mathrm{cd}}$ & $3.39 \pm 0.34^{\mathrm{e}}$ & $0.98 \pm 0.28^{\mathrm{d}}$ & $0.87 \pm 0.14^{\mathrm{de}}$ \\
\hline $\mathbf{L} 4 * \mathbf{R R}$ & $3.92 \pm 0.43^{\mathrm{c}}$ & $9.77 \pm 0.73^{b}$ & $3.36 \pm 0.68^{b}$ & $2.56 \pm 0.61^{\mathrm{c}}$ \\
\hline $\mathbf{L} 1 * \mathbf{U B}$ & $0.70 \pm 0.28^{\mathrm{d}}$ & $0.78 \pm 0.09^{f}$ & $0.29 \pm 0.07^{\mathrm{e}}$ & $0.40 \pm 0.15^{\mathrm{e}}$ \\
\hline $\mathbf{L} 2 * \mathbf{U B}$ & $20.22 \pm 9.37^{\mathrm{a}}$ & $14.75 \pm 2.66^{\mathrm{a}}$ & $6.68 \pm 0.78^{\mathrm{a}}$ & $11.20 \pm 2.14^{\mathrm{a}}$ \\
\hline $\mathbf{L 3} * \mathbf{U B}$ & $12.12 \pm 1.03^{b}$ & $7.38 \pm 0.86^{\mathrm{c}}$ & $3.24 \pm 0.56^{\mathrm{b}}$ & $4.78 \pm 0.40^{\mathrm{b}}$ \\
\hline $\mathbf{L} 4 * \mathbf{U B}$ & $14.05 \pm 0.65^{\mathrm{b}}$ & $9.52 \pm 0.67^{\mathrm{b}}$ & $2.99 \pm 0.43^{\mathrm{b}}$ & $4.71 \pm 0.42^{\mathrm{b}}$ \\
\hline
\end{tabular}

Note: Different letters over each column denotes statistical significant mean differences from Tukey's post-hoc test (p < 0.05)

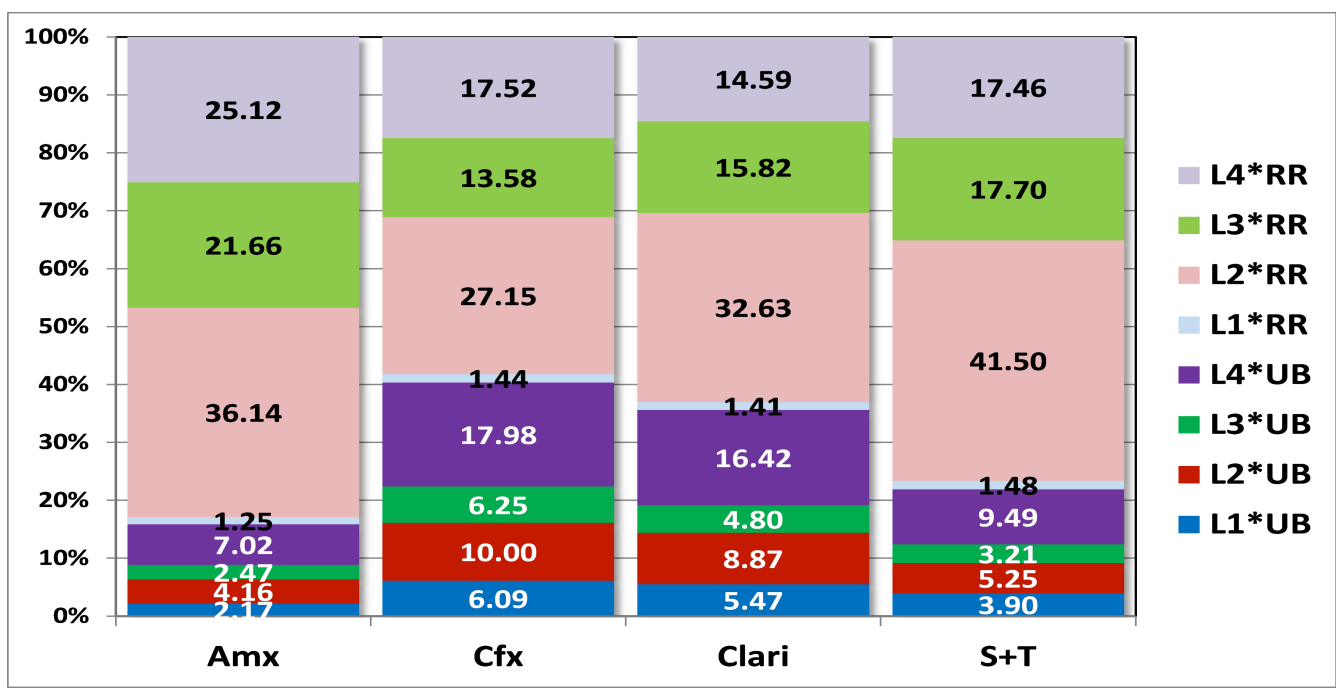

Figure 5.

Percentages of the children ${ }^{-1} \mathrm{~s}$ antibiotics use from different geographical areas

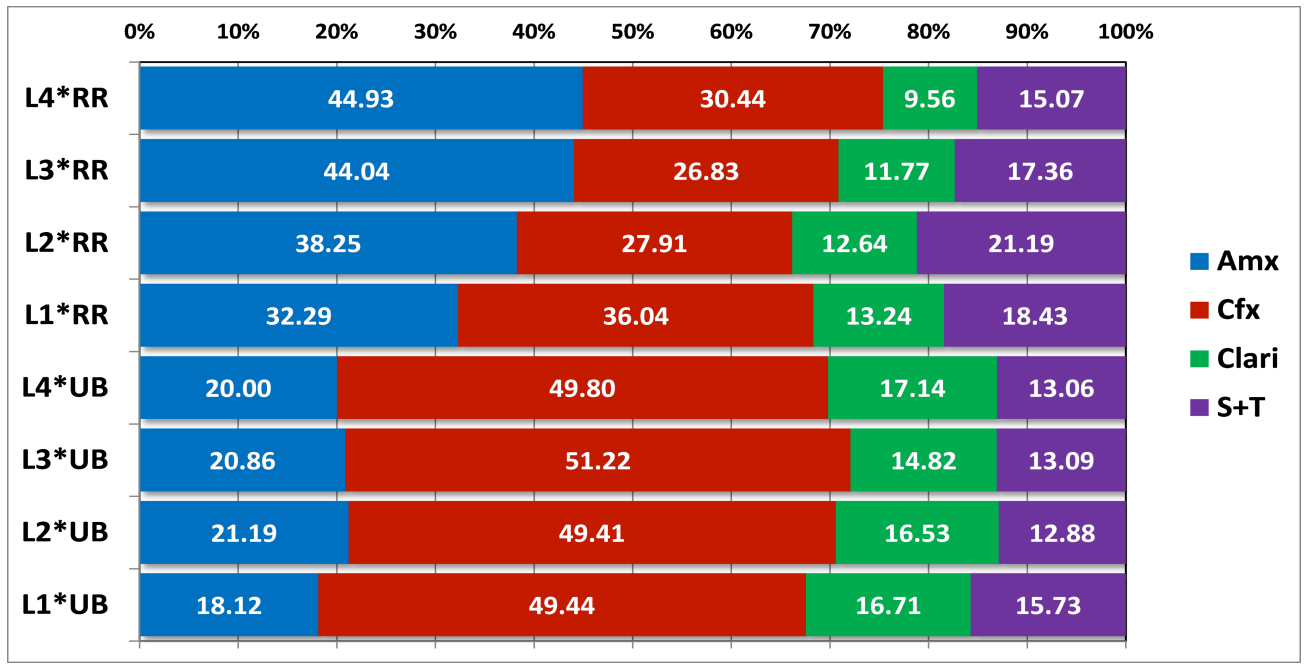

Figure 6.

Percentages of the children ${ }^{-1} \mathrm{~s}$ antibiotics average consumption distributed on geographical areas

Analysing the results of the study, we noted a higher consumption of antibiotics containing cefuroxime and clarithromycin in urban areas than in the rural ones. It was also noticeable that the mixture of sulfamethoxazole and trimethoprim was quite rarely used both by adults and children, maybe because it is a medicine the population has grown highly accustomed to. Although the price of this antibiotic is not high, being the cheapest in comparison to the other antibiotics in the study, it is not widely prescribed when compared to the more expensive antibiotics.

Given that the entire population is affected by treatment resistant bacteria, it is important for all the factors intervening in this chain which eventually 
leads to the use of antibiotics to be more involved and more responsible.

First of all, the patients' medical education is important. However, this education requires time, as we are talking about patients in pain, who are not always prone and receptive to the instructions provided by their attending physician/pharmacist. Another critical issue is the time the physician should allow for each patient to make sure the latter has understood the importance of the prescribed treatment. Since the time allocated to each medical examination is, however, limited and meanwhile the physician also has other obligations pertaining to the computerization of the health system, one can understand why patients tend to adjust their treatment as they see fit.

Once inside the pharmacy with the medical prescription, the pharmacist has to inform once more the patient on the way of administration, the duration of treatment and importance of strict observance of the course of medical treatment entirely. In the pharmacy, the time spent with the patient may be higher than the one in the doctor's practice, therefore the pharmacist's role is very important in fully clarifying the treatment to be administered to the patient.

Multivariate Analysis

The available data on antibiotics consumption allows us to determine which of the locations had highest overall antibiotics consumption. This purpose can be achieved by using a multivariate analysis sequence: the principal component analysis (PCA), one-way analysis of similitude (ANOSIM) and hierarchical cluster analysis (HCA).

The adults PCA statistics over the principal components is presented in Table I. The first two principal components manage to explain $99.41 \%$ of the total variance that is generated by locations and type of locations factors combined. The variables (i.e. antibiotics) loadings and samples (i.e. locations) scores from the PCA, are presented in the same plot, Figure 7, as a biplot. The PCA is an ordination multivariate method. The PCA biplot shows how the variables are correlated, by their vectors angles, and the relative antibiotic abundance differences between the location samples generates sample groups. The sample groups can form sample clusters.
In order to be able to point out the statistical significances of the sample clusters it was used the conjunction of ANOSIM and HCA multivariate methods. These methods used as input data the first two principal components (PC1 and PC2) values. The results are presented in Table II (for ANOSIM) and Figure 8 (for HCA). In Table II there are emphasized the statistical significances over the threshold, $\mathrm{p}<0.05$, that gathers those sample groups in the cluster. Results from Table II show five sample clusters; sample groups L1_RR, L2_RR and L3_RR became a singleton cluster and samples L3_UB and L4_UB, also joint in a singleton cluster. These validated five samples clusters, by ANOSIM $(\mathrm{p}<0.05)$, can be used in HCA (Figure 8 ) in order to determine the dissimilarity distance (in this case Euclidean distance) that correctly generates them. In the adults' case, the threshold dissimilarity distance was 2.75 (a.u.).

The PCA biplot was used to emphasise the adults sample clusters/locations that provided the highest overall antibiotics consumption. The variables (i.e. antibiotics) vectors helps to take decisions about the sample clusters antibiotics abundances. The sample clusters that are pointed by the vectors end points have the higher abundance of the corresponding antibiotics. If the sample clusters are located in the opposite direction, than there is the lowest abundance of the corresponding antibiotics. In this way, from the PCA biplot in Figure 7, the highest abundance of four antibiotics (variables Cfx, Cefix, $\mathrm{S}+\mathrm{T}$ and Clari) is present in clusters (L3_UB; L4_UB), L2_UB and L4_RR. The variable Amx has the highest abundance in L4_RR and (L2_RR; L3_RR and L1_RR) sample clusters. The overall antibiotics lowest consumption has the L1_UB sample cluster.

Table V

The principal component analysis statistics for adults' antibiotics consumption / thousand inhabitancies from each location

\begin{tabular}{ccc}
\hline PC & Eigenvalue & \% variance \\
\hline $\mathbf{1}$ & $\mathbf{4 . 2 4 2}$ & $\mathbf{8 4 . 8 4}$ \\
$\mathbf{2}$ & $\mathbf{0 . 7 2 8}$ & $\mathbf{1 4 . 5 6}$ \\
\hline 3 & 0.018 & 0.37 \\
4 & 0.008 & 0.17 \\
5 & 0.001 & 0.03 \\
\hline
\end{tabular}




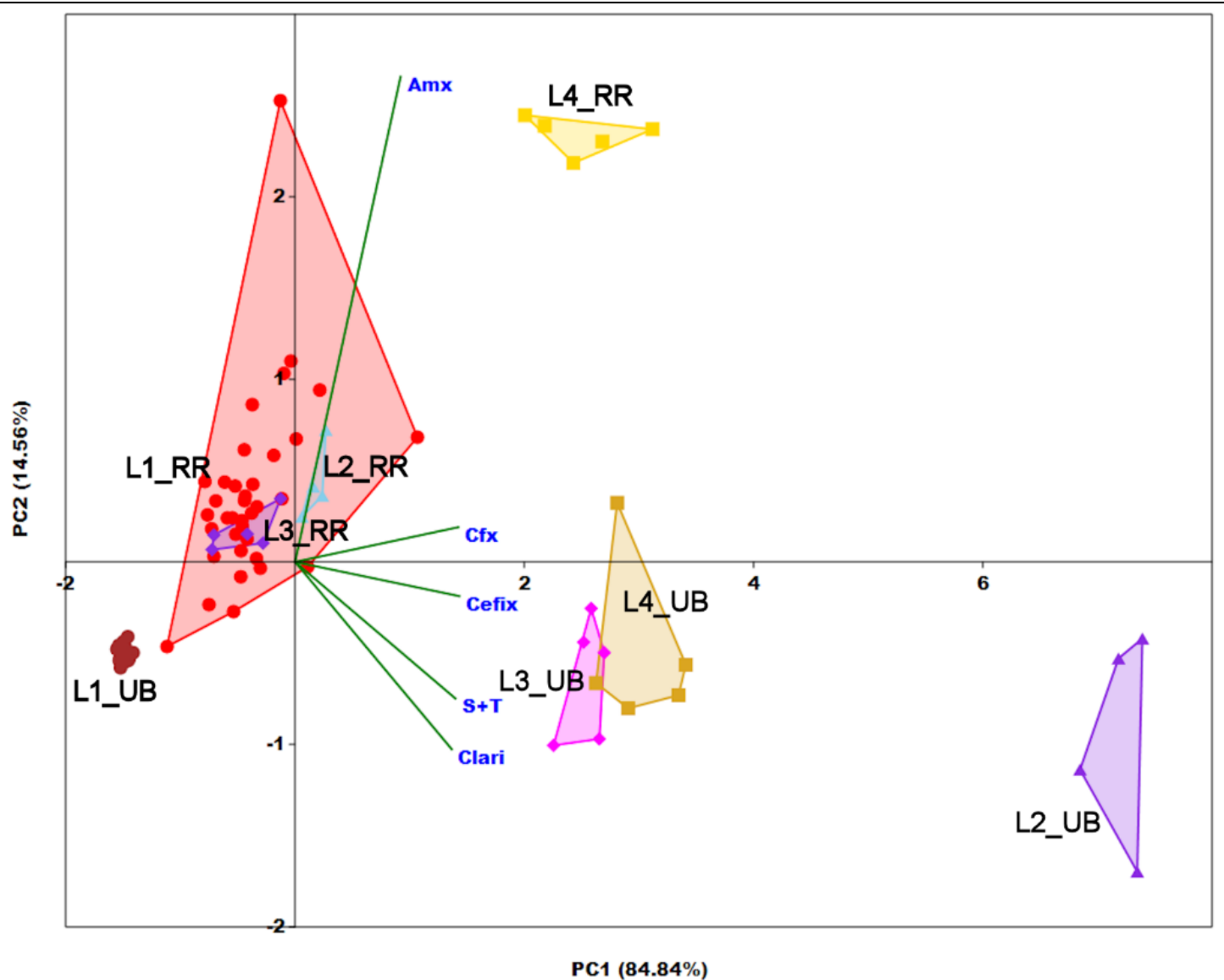

Figure 7.

The principal component analysis statistics for adults' antibiotics consumption / thousand inhabitancies from each location

Table VI

Statistical significances of one-way analysis of similitude (ANOSIM) with first two principal component values (PC1 and PC2) as input data - adults case

\begin{tabular}{c|cccc|cccc}
\hline $\begin{array}{c}\text { 1wANOSIM } \\
\text { (PC1+PC2) }\end{array}$ & L1_RR & L2_RR & L3_RR & L4_RR & L1_UB & L2_UB & L3_UB & L4_UB \\
\hline L1_RR & & $\mathbf{0 . 0 5 8}$ & $\mathbf{0 . 8 5 4}$ & 0.000 & 0.000 & 0.000 & 0.000 & 0.000 \\
L2_RR & $\mathbf{0 . 0 5 8}$ & & 0.017 & 0.008 & 0.000 & 0.031 & 0.008 & 0.007 \\
L3_RR & $\mathbf{0 . 8 5 4}$ & 0.017 & & 0.007 & 0.000 & 0.009 & 0.008 & 0.009 \\
L4_RR & 0.000 & 0.008 & 0.007 & & 0.000 & 0.008 & 0.007 & 0.009 \\
\hline L1_UB & 0.000 & 0.000 & 0.000 & 0.000 & & 0.000 & 0.000 & 0.000 \\
L2_UB & 0.000 & 0.031 & 0.009 & 0.008 & 0.000 & & 0.009 & 0.008 \\
L3_UB & 0.000 & 0.008 & 0.008 & 0.007 & 0.000 & 0.009 & 0.098 \\
L4_UB & 0.000 & 0.007 & 0.009 & 0.009 & 0.000 & 0.008 & $\mathbf{0 . 0 9 8}$ \\
\hline
\end{tabular}


FARMACIA, 2018, Vol. 66, 6

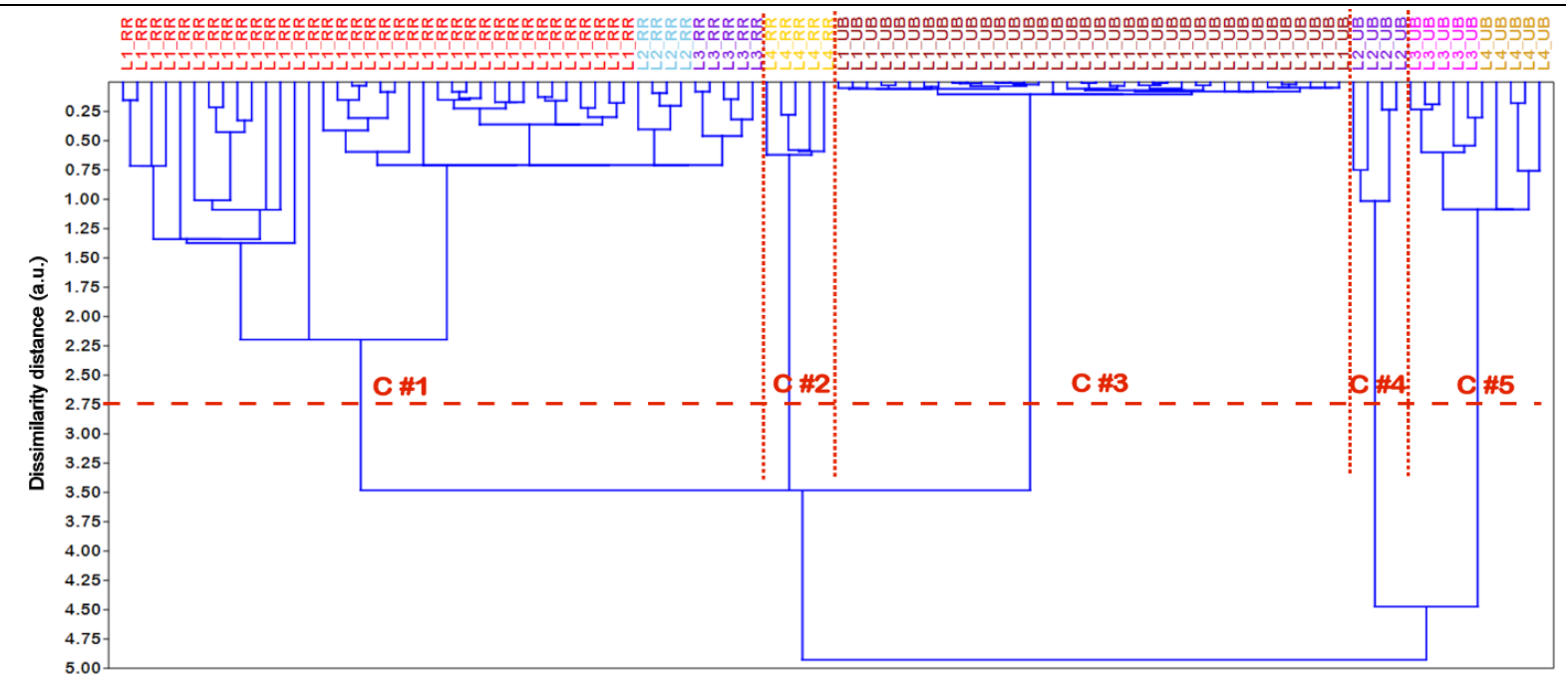

Figure 8.

Hierarchical cluster analysis (HCA) of first two principal component values (PC1 and PC2) as input data - adults case.

In the same way that we performed the sample cluster analysis of adults' antibiotics consumption, may be analysed the children's antibiotics consumption.
There are presented the multivariate sequence results in Tables VII and VIII, Figures 9 and 10.

The principal component analysis statistics for children's' antibiotics consumption/thousand inhabitancies from

\begin{tabular}{ccc}
\hline PC & Eigenvalue & \% variance \\
\hline 1 & 3.768 & 94.21 \\
2 & 0.174 & 4.34 \\
\hline 3 & 0.053 & 1.33 \\
4 & 0.004 & 0.10 \\
\hline
\end{tabular}

each location

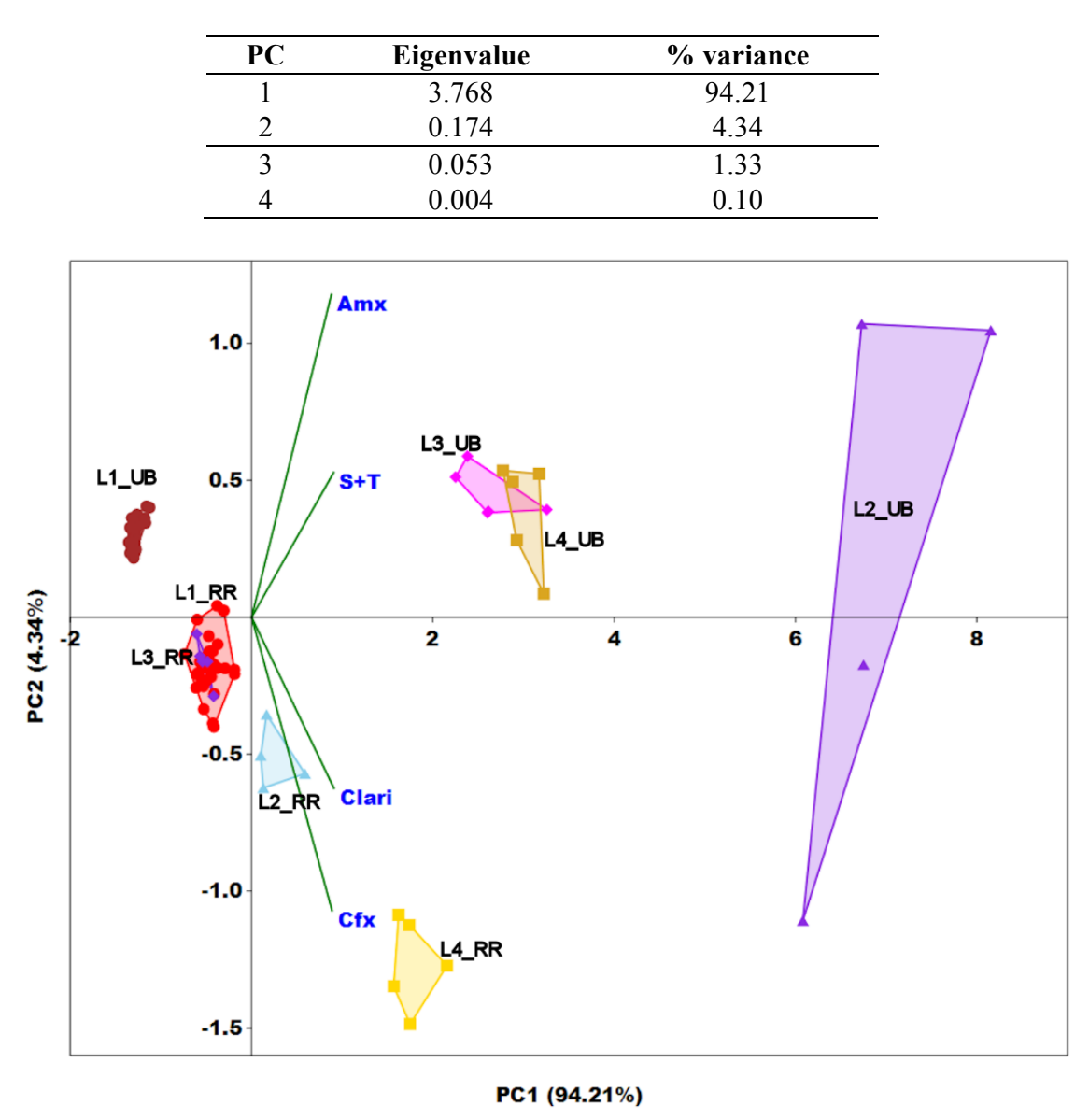

Figure 9.

The principal component analysis statistics for children' antibiotics consumption per thousand inhabitancies from each location 
Table VIII

Statistical significances of one-way analysis of similitude (ANOSIM) with first two principal component values

(PC1 and PC2) as input data - children ${ }^{-1} \mathrm{~s}$ case

\begin{tabular}{c|cccc|cccc}
\hline $\begin{array}{c}\text { 1wANOSIM } \\
\text { (PC1+PC2) }\end{array}$ & L1_RR & L2_RR & L3_RR & L4_RR & L1_UB & L2_UB & L3_UB & L4_UB \\
\hline L1_RR & & 0.000 & $\mathbf{0 . 6 7 0}$ & 0.000 & 0.000 & 0.000 & 0.000 & 0.000 \\
L2_RR & 0.000 & & 0.009 & 0.008 & 0.000 & 0.028 & 0.007 & 0.009 \\
L3_RR & $\mathbf{0 . 6 7 0}$ & 0.009 & & 0.010 & 0.000 & 0.008 & 0.006 & 0.009 \\
L4_RR & 0.000 & 0.008 & 0.010 & & 0.000 & 0.009 & 0.008 & 0.006 \\
\hline L1_UB & 0.000 & 0.000 & 0.000 & 0.000 & & 0.000 & 0.000 & 0.000 \\
L2_UB & 0.000 & 0.028 & 0.008 & 0.009 & 0.000 & & 0.008 & 0.009 \\
L3_UB & 0.000 & 0.007 & 0.006 & 0.008 & 0.000 & 0.008 & & $\mathbf{0 . 0 8 8}$ \\
L4_UB & 0.000 & 0.009 & 0.009 & 0.006 & 0.000 & 0.009 & $\mathbf{0 . 0 8 8}$ & \\
\hline
\end{tabular}

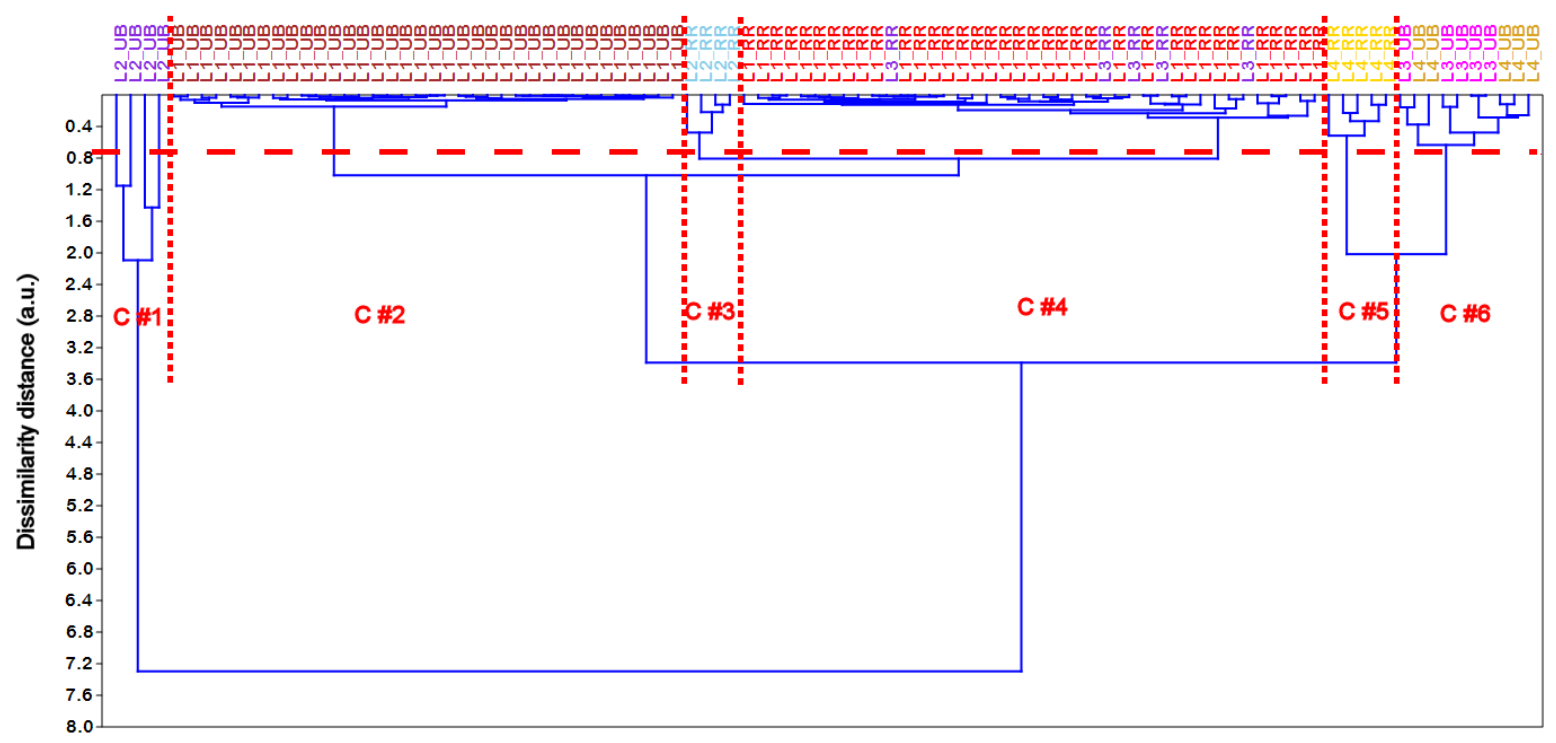

Figure 10.

Hierarchical cluster analysis (HCA) of first two principal component values (PC1 and PC2) as input data children ${ }^{-1}$ s case

There are six sample clusters, as a consequence that samples L1 RR with L3 RR and L3 UB with L4_UB gathers in two singleton clusters.

The location that had the highest overall antibiotics consumption was the L4_RR, followed by locations L3_UB, L4_UB and L2_UB.

The clusters L2_UB and (L3_UB; L4_UB) had the highest abundance of variables Amx and S+T. The clusters L4_RR, L2_RR and L2_UB had the highest abundance of variables Clari and Cfx. Thus the location L2_UB has the highest overall antibiotics consumption for children

\section{Conclusions}

The patient must be responsible and follow through the therapeutic scheme in order to avoid situations in which any given treatment fails to be efficient due to the development of antibiotic-resistant strains. Unnecessary use of antibiotics compromises their efficiency precisely where we need them, in bacterial infections. Antibiotics must be used in a responsible way and only when they have been prescribed and advised by a healthcare professional, physician, pharmacist.

Everyone is responsible for keeping antibiotics effective, as only their responsible use can stop the development of resistant bacteria. Showing down the development of resistant bacterial strains will maintain the efficiency of antibiotics for future generations.

\section{References}

1. Barabás R, Rigó M, Eniszné-Bódogh M, Moisa C, Cadar O, Preparation and characterization of hydroxyapatite based nano-composite biomorphic implants. Studia UBB Chemia, 2018; LXIII(3): 137-154.

2. Carac A, Boscencu R, Dediu AV, Bungău SG, Dinica RM, Solvent effects on the spectral and electrochemical properties of some pyridinium quaternary compounds. Revista de Chimie, 2017; 68(7): 1423-1428.

3. Fisher RC, Patient education and compliance: A pharmacist's perspective. Patient Education and Counselling, 1992; 19: 261-271. 
4. Hammer O, Harper DAT, Ryan PD, PAST: Paleontological statistics software package for education and data analysis. Palaeontologia Electronica, 2001; 4(1): 9.

5. Iancu M, Bucșa C, Fărcaș A, Leucuța D, Dincu A, Mogoşan C, Dumitraşcu D, Bojiţă M, Patient's counselling and management of adverse drug reactions and drug interactions in the community pharmacy. Farmacia, 2015; 63(1): 80-85.

6. Minarikova D, Malovecka I, Foltan V, Patient choice of pharmacy and satisfaction with pharmaceutical care - Slovak regional comparison. Farmacia, 2016; 64(3): 473-480.

7. Mirea L, Niţipir C, Grinţescu IC, Băetu A, Gîngu R, Arsene AL, Grintescu IM, Efficacy of tigecycline treatment in severe and complicated Clostridium difficile infection. Farmacia, 2017; 65(4): 600-604.
8. Moisa C, Vicaș L, Ganea M, Levei E, Cadar O, Berce $\mathrm{C}$, Murine studies regarding the tissue intake of different magnesium compounds. Farmacia, 2018; 66(1): 176-180.

9. Moisa C, Hoaghia MA, Simedru D, Cadar O, Influence of tablet formulation on in vitro release of magnesium. Studia UBB Chemia, 2016; LXI(3): 441-449.

10. Taerel AE, Rosenberg L, Nicolescu T, Ethics and equity in providing pharmaceutical assistance to the population. Revista Romana de Bioetica, 2010; 8(1): 150-154.

11. Toklu ZH, Hussain A, The changing face of pharmacy practice and the need for a new model of pharmacy education. J Young Pharmacists, 2013; 5(2): 38-40. 